\title{
The Influence of Colonialism and Donors on Social Policies in Kenya and Tanzania
}

\author{
Daniel Künzler
}

\section{Introduction}

Kenya and Tanzania are two neighboring countries in East Africa that inspired a number of paired comparisons in the 1970s and 1980s (e.g. Cliffe 1973; Barkan 1984). ${ }^{1}$ These mainly investigated the effects of different economic and political systems but neglected social policies. The comparisons were based on the assumption that the two countries are quite similar in terms of cultural heritage and natural setting: both are located on the East African coast, have a British colonial legacy and house significant pre-colonial Muslim populations. According to the literature, these similarities should produce a similar colonial tax income (Frankema

\footnotetext{
${ }^{1}$ Tanganyika is used for the colonial period and Tanzania for the period after independence, although Tanganyika gained independence under this name and was renamed United Republic of Tanzania three years later, with the unification of Tanganyika and Zanzibar.
}

D. Künzler $(\bowtie)$

Department of Social Work, Social Policy and Global Development, University of Fribourg, Fribourg, Switzerland e-mail: daniel.kuenzler@unifr.ch 
and van Waijenburg 2014). A similar colonial tax income ought, in turn, to be linked to a similar post-colonial tax income and post-colonial social policy development (Mkandawire 2010, 2016).

However, a look at human development indicators reveals considerable differences between the two countries. In 2015, a Kenyan baby had a life expectancy of 62.2 years at birth and could expect to receive 11.1 years of schooling (UNDP 2018). In neighboring Tanzania, a baby had a longer life expectancy (65.5 years) but could expect considerably less schooling (8.9 years). On average, each of the Kenyan baby's parents had an income of US \$2881 (purchasing power parity of 2011), while the Tanzanian baby's parents were somewhat poorer, with an income of US $\$ 2467$ each. The Kenyan parents are less likely to be poor, as 36\% of the Kenyan population lives in poverty, compared to $66 \%$ in Tanzania. ${ }^{2}$

Thus, Kenya and Tanzania do not really fit the theory. This makes the longer-term social policy trajectories of Kenya and Tanzania a promising research gap for a comparative study. Such a study will help especially with achieving a better understanding of differences within British colonialism and its legacies, assuming that the comparatively brief period of German colonialism in Tanganyika (1885-1918) is hardly formative for later social policies. ${ }^{3}$ However, colonialism was not the only form of external influence, and it is important to also look at key post-colonial periods. This paired comparison thus tackles the following research question: What is the influence of external actors on social policies in Kenya and Tanzania?

Initially, the literature on colonial social policies and the empirical evidence for Kenya and Tanganyika are presented. The following sections then deal with the influence of donors in post-colonial Kenya and Tanzania in the following key periods. The first key period especially relevant for health care was during structural adjustment around the 1980s. The second key period begins with the turn of the millennium. It concerns the fields of health care and education and finally also the fields of pension policies and cash transfers. Lastly, the interplay between external

\footnotetext{
${ }^{2}$ This comparison is based on the indicator "Population in multidimension poverty, headcount (\%)".

${ }^{3}$ The umbrella term "colonialism" is used here also for mandates, trusteeships and protectorates.
} 
actors and national factors and differences between Kenya and Tanzania are discussed in the section preceding the conclusion.

\section{Colonial Influences on Social Policies}

\section{Theorizing International Influences on Domestic Social Policies: Differences Within British Colonial Social Policies}

The first section looks at one key external influence: colonialism. Before presenting empirical evidence on colonial social policies in Kenya and Tanganyika, it starts by picking up some threads of the introduction and discussing the literature on colonial social policies more generally. In contrast to Frankema and van Waijenburg (2014), Mkandawire (2010, 1652) claims colonial Kenya to have a higher per capita tax income than Tanganyika. The theoretical explanation for this claim is based on the literature and especially on Amin (1972) and points to the different ways these colonies were incorporated in the colonial economy. It is thus able to explain differences within British colonialism.

According to Mkandawire (2016), Kenya was a labor reserve economy. Concentrated in Southern and Eastern Africa, this type depended on cheap African waged labor. The education of Africans and independent forms of income were minimized; levels of land alienation and direct taxation were high, to push Africans toward waged labor. With the growth of the export industry, trade taxes became increasingly important but never completely substituted for direct taxation. High taxation was also necessary to finance the racially exclusive welfare regimes established for the white (male) population. As Künzler and Nollert $(2017,8)$ summarize this theoretical argument: "The exploitation of labour was based on burdening its reproduction on rural communities kept at subsistence level. Social policy was dependent on employment in the formal sector of the economy. The poor non-employed urban population was kept to a minimum and social policies based on the English Poor Laws were targeted at this group" (see also Schmitt, Chap. 6, this volume). In labor 
reserve economies, the colonial state was strong. The post-colonial legacy of labor reserves includes high inequality, a higher HIV prevalence rate and racialized social policies, but also a broader tax base that can potentially finance the extension of social policies.

In contrast, again according to Mkandawire (2016), Tanganyika was one of the few East African cash crop economies. ${ }^{4}$ This type is mainly located in West Africa and is characterized by smallholder peasant access to land. African peasants could control their agricultural production and participated directly in international commodity markets. This allowed them to invest in the education of their children. Mkandawire (2016) assumes that cash crop economies thus had higher school enrolment rates during colonial times and that social protection was informally provided and community-based. The final assumption is a post-colonial legacy of a weak tax base linked with lower social expenditures.

To summarize the theoretical argument, Tanzania was incorporated into the colonial economy as a cash crop economy. Theoretically, this should mean mainly informal or community-based forms of social protection in colonial times and low post-colonial social expenditures. In contrast, Kenya is classified as a labor reserve and expected to have a more elaborated system of social welfare for the white settlers. While social policies for Africans during colonial times were supposedly focused on formal employment and, in a very limited capacity, the urban poor, postcolonial social expenditures are expected to be higher. What is the empirical evidence for these theoretical assumptions?

\section{Colonial Social Policies in Kenya and Tanganyika}

This subsection will demonstrate that Kenya differs from the theoretical labor reserve model in two key aspects. First, it will demonstrate that agricultural production could support the rural poor and, second, that there was no significant welfare system for white settlers. It will then

\footnotetext{
${ }^{4}$ Amin (1972), on whose work Mkandawire (2016) builds, classified what he called German Tanganyika as a labor reserve, or more precisely as settler agriculture driving rural communities into reserves. However, in the subsequent literature colonial Tanganyika is described, in line with Mkandawire (2016), as a cash-crop economy (e.g. Cliffe 1973).
} 
show how the general orientation of colonial social policies in Kenya and Tanganyika was quite similar and also that some selected policy fields (old-age pensions, minimum wages) differed less than the theory assumes. It then looks at another policy field (education), where the empirical data do not really fit to the theoretical differences. Finally, this subsection points to the extent to which the responsibility of the central colonial state differed in Kenya and Tanganyika, a key difference that is in line with the theory.

The labor reserve model was developed with classic examples such as South Africa in mind. While colonial Kenya did indeed have a substantial settler population and large-scale farms, it differed from the model in two key respects. First, the areas that supplied labor were also the centers of the production of cash crops by African farmers. This production went beyond what was needed for the reproduction of waged labor. It was oriented toward domestic and international markets and continually expanded, not least during the Second World War, when both the settler farming sector and African farmers could capitalize upon the circumstances (Anderson and Throup 1985). Agricultural production could support the rural poor. While Mkandawire $(2010,6)$ acknowledges that "various forms of market incorporation took place within the same economy", he did not name Kenya as an example. To a certain extent, Tanganyika too combined cash crop production with the supply of labor for plantations (see also Amin 1972). Second, while there was a dual policy of segregation in Kenya, there was no significant welfare system for white settlers, "presumably because there had never been a strong white working-class or a white urban poor demanding public welfare schemes" (Seekings 2005, 27).

In line with Mkandawire's $(2010,2016)$ claim, colonial Kenya had a higher extractive capacity and a higher per capita tax income than Tanganyika (Frankema and van Waijenburg 2014, 383). ${ }^{5}$ The two colonies had different financial resources. This should theoretically result in differences in colonial social policies. However, as agricultural production in both colonies could support the rural poor, the general orientation of colonial social policies was surprisingly similar. In colonial Kenya,

\footnotetext{
${ }^{5}$ Mkandawire $(2010,1652)$ himself uses post-colonial data to substantiate his argument.
} 
officials attempted to preserve rural family and communal ties and revive them when economic changes put the idealized agrarian society under pressure (Lewis 2000; Seekings 2005). Increasing urbanization led to some urban welfare initiatives. Only with the return of African soldiers after the Second World War did the Colonial Office in London and colonial officers in Nairobi see the need for intervention, but they "diverged in their visions" (Lewis 2000, 244) and met resistance from the white settlers. Finally, as in the rural areas, a logic focusing on family and communal ties was applied and urban community development was promoted. As part of the demobilization program, ex-servicemen were used as community development workers. The idea of offering gendered education and literacy training in community centers had a short boom and was followed by a productivist turn, leaving social welfare to community initiatives.

What happened in the neighboring cash crop colony of Tanganyika was broadly similar, despite differences in detail. There were isolated colonial welfare initiatives in urban areas before the Second World War. The engagement of the colonial state in the field of urban welfare in Tanganyika also increased in the context of returning African soldiers, when shortlived welfare centers were established with the aim of integrating exservicemen and offering gendered education and literacy training (Eckert 2004). There were differences between London and colonial officials in Tanganyika concerning their respective visions. However, generally the policy of the colonial administration "attempted to strengthen the efficiency and influence of traditional institutions in the field of social security" (Eckert 2004, 475).

Within the scope of this chapter it is not possible to look in detail at all social policy fields. In the following, old-age pensions and minimum wages are discussed to show that these policy fields were less different than theory would assume. The picture would be similar for other policy fields, such as health care or social protection against employment injury. Concerning old-age pensions, workers in Kenyan government service had a certain coverage, but there was a fairly distinct racial divide on the formal labor market. There was a common agreement that a more comprehensive pension coverage was needed, but there were long debates about what the exact nature of such a pension scheme would be. A 
committee appointed in 1953 to study social insurance (Clayton and Savage 1974) recommended a contributory pension fund. However, independence was imminent, and the matter was left. In Tanganyika, the colonial administration was also not supportive of a compulsory provident fund for non-governmental formal sector workers (Eckert 2004, 475). Lower ranks of government service were covered by the provident fund of 1942 (Bossert 1985). ${ }^{6}$ Both Tanganyika and Kenya fit in the general pattern of British colonies, as more comprehensive social protection for old age was introduced only after independence (Schmitt 2015).

Old-age pensions were among the demands of Kenyan labor movements in their frequent strikes (Singh 1969). ${ }^{7}$ However, the emphasis was more on the acceptance of unions, political participation of Africans and especially minimum wages, housing and working conditions (Singh 1969; Clayton and Savage 1974). Especially after the Second World War there was a significant policy change: As a means of stabilizing the workforce, the minimum wage was no longer deemed to be intended to provide for a bachelor but for an urban family and was raised considerably (Neubert 1986, 90-91). However, this minimum wage was based on a very narrow conception of a nuclear family and was also supposed to solve housing problems. Family allowances were not common in colonial Kenya, as they were considered to impede the competitivity of male workers with children on the labor market (Neubert 1986, 91). Tanganyika had a Minimum Wage Ordinance from 1939 on, but there was no mechanism for wage fixing and thus, in contrast to Kenya, de facto no minimum wage during the colonial period (Bryceson 1990).

Looking at another policy field, education, there are differences between Kenya and Tanganyika, but not in the way claimed by theory. According to Mkandawire (2016), enrolment should be higher in Tanganyika. This is not the case: At the end of the colonial period Kenya had higher primary and secondary education enrolment rates (Künzler 2007, 75). But Kenyan enrolment was highly unequal, and a substantial

\footnotetext{
${ }^{6}$ In principle, higher ranks could expect pensions from 1932 on, but there were no Africans in such positions (Bossert 1985, 102).

${ }^{7}$ Labor movements also referred to the ILO to back this claim.
} 
part of the education budget went to a small number of children of European settlers.

However, focusing too narrowly on colonial social policies might miss a more indirect effect linked to the lower extractive capacity of Tanganyika. The late colonial state in Tanganyika was more modest in spending and placed greater emphasis on engagement at the local level. In contrast, the colonial state in Kenya had a more top-down, interventionist manner and spent more. In line with other labor reserves (Mkandawire 2016), colonial Kenya introduced, in 1919, strong racially exclusive policy measures to manage labor migration by way of registration. "The registration system brought virtually the entire adult male African population under much more direct administrative control, and made it possible to trace back to the reserves and arrest deserters and other violators who failed to be properly signed off by an employer" (Berman and Lonsdale 1992, 112-113). This registration system was a tool to raise African taxes, but proof of employment also exempted Africans from compulsory labor. The hated system was abolished in 1947, but a somewhat similar passbook system was introduced among ethnic groups mostly linked to the Mau Mau insurgency that officially lasted from 1952 to 1960 . Also this insurgency contributed to the top-down interventionist nature of the colonial state.

In many ways, the legacy of the colonial period is not linked to different social policies but rather to the differing extent to which the central colonial states were responsible for social policies. One example of this is famine relief. Colonial Kenya introduced measures such as free famine relief, free school meals, work-for-food programs or the provision of foodstuffs for markets on subnational levels. However, as early as 1918, reactions to food shortages were centrally coordinated by the colonial government (Maxon 1980). During the famine of 1960, too, the central administration became involved, and food for famine relief was imported in the context of a coordinated operation. By contrast, in Tanganyika famine relief was initially an ethical imperative for district-level administrators rather than a government obligation (Bryceson 1990). It was quite elementary and never a national task or a right.

Thus, contrary to the theoretical expectation, the general orientation of colonial social policies was surprisingly similar in Kenya and 
Tanganyika. However, the central colonial state was less directly responsible for social policies in Tanganyika. These differences in responsibility continued in the years following independence, and the emphasis on local-level engagement and questions of affordability were more important in Tanzania than in Kenya. ${ }^{8}$ Within the scope of this chapter it is not possible to describe the 1960s and 1970s in detail, and these decades are skipped to have enough space for the following decades when the influence of international actors in the field of social policies is more pertinent. Indeed, the dominant models of social policies championed by international actors during the 1960s and 1970s were quite in line with domestic priorities, based on both a modernization framework that emphasized formal sector-based social security and government planning of social services. Thus, the next section picks up the thread starting in the 1980s, because this is a key period to discuss the influence of international donors.

\section{The Influence of Donors During Structural Adjustments Around the 1980s}

The second key influence after colonialism discussed in this chapter is international donors. Again, literature assumes them to be important drivers of social policy-making in the Global South (e.g. Niño-Zarazúa et al. 2012). There is ample empirical evidence that suggests that this was the case around the 1980s, for example when donors such as the World Bank and the International Monetary Fund (IMF) pushed national governments to implement structural adjustment programs. They generally included the cutting of budgets for the civil service or for social expenditures and were accompanied by the introduction of official user fees in the health care and/or education sectors (e.g. Künzler 2007, 2016c). Lacking viable alternatives, many sub-Saharan African countries

\footnotetext{
${ }^{8}$ The focus on the informal social welfare system of the community, described above for British colonies, continued after independence: The Kenyan Harambee movement asked communities to support social services with labor, building materials and money. In Tanzania the situation was different, as community participation in development was partly enforced top-down.
} 
were dependent on the financial backing of these international financial institutions and introduced such policies, sometimes backed by internal actors. However, there is also evidence of national governments only paying lip service to international obligations. There seem to be limits to donor influence.

Unfortunately, the observation by Boyle, Songora and Foss (2001, $524)$ is still quite correct: "No comprehensive sociological theory explains this variation in the adoption of policies promoted through the international system." The World Polity Theory acknowledges differences in the adoption of global policy models under the label of "de-coupling" and points to the influence of two factors: relevance and leverage (Boyle et al. 2001). A necessary condition for de-coupling to occur is adverse relevance of a policy proposal for domestic key constituencies. However, decoupling is more likely and greater in countries with more leverage in the international system. ${ }^{9}$ Richer countries have more leverage than poorer (e.g. post-conflict) countries, but geo-strategic importance also matters.

The empirical evidence for donor influence in Kenya and Tanzania after the late 1970s shows that Kenya indeed had more room for manoeuver than Tanzania. After the death of President Kenyatta in 1978, the new president Moi pledged to follow the footsteps of his predecessor. Some of his early decisions were indeed reminiscent of earlier policies (increase of minimum wages, systematic hiring of graduates, national famine relief). However, Kenya had increasing financial problems and became more dependent on international financial institutions. Kenya became one of the first countries to receive a structural adjustment loan after it had devaluated its currency and slowed down government hiring.

The Kenyan government announced user charges in two subsequent development plans (1979-1983 and 1983-1988), however, without introducing them. In the next development plan (1989-1993) this commitment to introduce user charges was replicated, and finally user charges were announced. After a public outcry the government used the more acceptable term of "introduction of cost-sharing" to communicate the same thing: the end of free health care (Mwabu 1995, 248). A costsharing scheme was hastily introduced in 1989, under "considerable pres-

\footnotetext{
${ }^{9}$ Niño-Zarazúa et al. $(2012,165)$ mention such a difference without much discussion.
} 
sure from donors" (Mwabu 1995, 248). After only nine months of implementation, the suspension of outpatient fees was abruptly communicated in the mass media. The reason was that media reported the disastrous effects of the fees on the poor and vulnerable and that the government came under pressure. It is unclear if the imminence of the first multiparty elections, of December 1992, also played a role. However, in April 1992, shortly after the suspension, the Kenyan government announced the reintroduction of facility-dependent outpatient fees, again through mass media (Mwabu 1995, 248). In reaction to earlier criticism, the new fees were to be charged after the patient was treated, and there were unclear exemptions. There were no protests anymore (Mwabu 1995, 252).

Tanzania also came under economic pressure and was confronted with international financial institutions and their technocratic structural adjustment demands. Like Kenya, Tanzania tried to manoeuver in the space available. In 1981, a domestically crafted program was launched. However, donors doubted the sincerity of the government and reduced aid. This pushed government, in 1982, to a structural adjustment program that included the partial removal of maize price subsidies, cushioned by a rise of the minimum wage. In contrast to the country's first president Nyerere, his successor Mwinyi was less reluctant to introduce economic reforms (D’Arcy 2013, 233). In 1986, the donor-backed economic recovery program introduced user fees for education. Other donor-backed programs followed and included the formal introduction of health care user fees in 1993, strongly pushed by donors and complemented by an exemption and waiver policy. Politicians were hesitant, but there was some domestic support from bureaucrats (Pedersen and Jacob 2018, 7). Multiparty elections were introduced only after this policy change, and the opposition unsuccessfully promised to abolish the user fees.

Thus, while both countries support the theoretical assumption that the influence of international donors was quite high during the period of structural adjustment, there were differences in terms of room for manoeuver. Tanzania has less leverage in the international system and was quickly sanctioned (see Devereux and Kapingidza, Chap. 11, this volume). The introduction of multiparty elections is another crucial effect of donor influence that had important consequences for later social policies 
(D'Arcy 2013). This will become evident in the discussion of the influence of donors after 2000 in the fields of health care and education (next section) as well as pensions and cash transfers (following section).

\section{The Influence of Donors After 2000: The "Millennium Development Goals" (MDGs)}

After 2000, the MDGs received a great deal of attention from international donors. Especially goals 2 to 5 became important for the domestic political agenda in Kenya and Tanzania. Goals 2 and 3 concerned education and called for an expansion of enrolment to achieve universal primary education and gender equality in primary, secondary and later also tertiary education. Goals 4 and 5 focused on the reduction of child and maternal mortality rates. In contrast to the remaining goals, Goals 2-5 are in line with two potential domestic priorities: they can be framed as being productivist and have a broad electoral appeal. However, there is an important difference between health care and educational goals. There are no clear models in global health care policies (Kaasch 2013), and countries therefore can choose different policies in the name of attaining global goals. This subsection will show that donors are somewhat influential, but the resulting national politics in the health care sector are quite varied and inconsistent. In the domain of education there was a wide international consensus that user fees had to be abolished in order to raise enrolment. Even the World Bank, deviating from its earlier cost-sharing policies, argued against user fees in primary education. As discussed below, both countries abolished user fees and followed the international prescription.

In Kenya, school fees were an important topic of the electoral campaign in the run-up to the contested Kenyan presidential election of 2002. The governing party wanted to reduce fees, while the oppositional coalition promised to abolish them. Shortly after winning the election, the new president, Kibaki, from the oppositional coalition summarily declared free primary education. This policy was financially supported by the World Bank and the UK Department for International Development 
(DFID) and other donors. The government proposed a new "National Social Health Insurance Fund" (NSHIF) to replace the "National Health Insurance Fund" (NHIF), with advice by the World Health Organization (WHO) and the then Deutsche Gesellschaft für Technische Zusammenarbeit (GTZ) (Künzler 2016a, 10). Parliament passed a highly controversial bill in December 2004, but President Kibaki declined to sign it into law, and the unsigned bill later lapsed. In parallel, government also partly removed health care user fees. Another significant reform was again summarily introduced shortly after the 2013 presidential election. The winner, Uhuru Kenyatta, represented a new coalition and shortly after the election declared that public maternity services would henceforth be for free (Künzler 2016a, 6-8). While there was no direct donor support for this policy, donors are generally quite important for the financing of the Kenyan health system. An important campaign issue of both the governing party and the main opposition coalition in the 2017 election was free secondary education. After his re-election, Uhuru Kenyatta introduced this policy with effect from January 2018, until now without any known major donor support.

In Tanzania, in the run-up to the second multiparty presidential elections of 2000, several candidates, including the incumbent successor of Mwinyi, Mkapa, "promised to reduce or abolish primary school fees, which they perceived to be a widespread concern among voters" (Kjær and Therkildsen 2013, 597). D'Arcy $(2013,235)$ cites a civil society observer who described the promise as "definitely a vote winner" and concludes that the abolition of school fees would "yield a particularly high political return for the government". After being elected for his second term, Mkapa fulfilled his promise and re-introduced free primary education. While the political return of such a policy change was surely quite high for the government, there was also "public pressure during the Poverty Reduction Strategy Paper process and (...) active lobbying of the president by the World Bank Country Director, who was keen to repeat Uganda's UPE [Universal Primary Education, dk] success in Tanzania" (Kjær and Therkildsen 2013, 597). However, pressure was associated with financial support through a World Bank loan in the form of debt relief for the social sectors. According to D'Arcy (2013, 236), "the removal of fees would not have been feasible without the help of donors". 
Secondary education was also a topic in the 2005 presidential elections, as a result of which Kikwete succeeded Mkapa. However, the electoral promise was an expansion of the lower secondary education infrastructure, pushed less by Kikwete than by Prime Minister Lowassa, who later became an oppositional presidential candidate (Languille 2015). This policy choice does not follow the preference of international donors for the abolition of school fees but is still in line with the MDGs. ${ }^{10}$ However, free secondary education was declared shortly after the election of the new president, Magufuli, in 2015 without major donor support.

As D'Arcy (2013) emphasizes, the government of Tanzania remained committed to cost-sharing in the health care sector. She explains this by the lack of significant donor funding for a fee-removal policy. While a few donors such as DFID and UNICEF were supportive of the removal of health care fees, others, including the World Bank, were more ambiguous. The switch of DFID to General Budgetary Support in 2002 weakened the fee abolition position. Yet other donors supported community (e.g. Swiss Agency for Development and Cooperation) or national (GTZ) health insurance schemes. Consequently, the NHIF was introduced in 1999, focusing on public sector employees and their dependents. In 2001, the "Community Health Fund" was introduced for the informal sector. The term "community" refers to local involvement in the management of the fund. From 2007 on the NHIF mandatory also covered formal sector workers in the private sector. There are discussions to make the NHIF compulsory for all Tanzanians. There are also patchwork attempts at reforms in the health sector without donor support, for example, by providing free health insurance cards to poor pregnant women and their households or by plans to make NHIF membership mandatory for all citizens.

In a nutshell, while national governments followed the clear international prescriptions in the domain of education, this was not the case in the domain of health care, where there was more room for manoeuver.

\footnotetext{
${ }^{10}$ It represented a rupture with the educational policy of Nyerere which strongly emphasized primary education and limited secondary education to a meritocratic elite (Languille 2015).
} 


\section{Pension Policies and Cash Transfers Since the Turn of the Millennium}

\section{Pension Policies}

There is also some room for manoeuver for national governments in the field of global pension policy, but for different reasons. In this field there is contestation between policy models (Kaasch 2013). The historically older model, social insurance, is pushed by an epistemic community around the International Labour Organization (ILO). The second model emerged around the World Bank and promoted a three-pillar pension system with a strong emphasis on privately funded and managed pension schemes. While the second model was for some years highly influential in Central and Eastern Europe, it was less influential in sub-Saharan Africa (Kpessa and Béland 2012). The World Bank later adapted its policy model and included social pensions. More recent publications are more cautious and no longer recommend a clear policy model (Künzler 2016c). The field of pension policies shows quite clearly that the prescriptions of international donors are not static but constantly revised and adapted. Different donors might favor contradictory policies at certain moments. Donor influence is higher when this is not the case (see Shriwise, Chap. 2 , this volume).

Both countries sought and followed ILO advice for pension reforms. In Kenya, the "National Social Security Fund" (NSSF) was in 2013 turned from a lump-sum provision scheme into a pension scheme with monthly payments (Künzler 2016b). Early 2020, contributions to be deducted from civil servants' pay were announced. In Tanzania, the transformation of the "National Provident Fund" (NPF) into the NSSF was decided in 1996. Monthly payments were introduced and coverage was extended to former non-pensionable employees of the central government, the formal private sector and the self-employed. In 1999, the previous non-contributory pay-as-you-go pension system for employees of the central government was changed to a contributory scheme offering a monthly pension. However, in recent years the focus switchedas it did in Kenya - to cash transfers, the topic of the next subsection. 


\section{Cash Transfers}

Cash transfers are used in several policy fields, and different donors support different varieties of cash transfers. Empirical evidence shows that African countries with more financial resources (leverage) and also some poorer countries used their room of manoeuver and adopted unconditional cash transfer programs with the support of various donors (Simpson 2018). In contrast, poorer countries more frequently adopted conditional cash transfer programs with support from the World Bank. Indeed, Kenya adopted unconditional cash transfers supported by the World Bank and other donors, while Tanzania introduced a conditional cash transfer with support of the World Bank and other donors.

In Kenya, UNICEF used the run-up to the 2002 elections to campaign for orphans and vulnerable children and made parliamentary candidates sign a call to action (Alviar and Pearson 2009). More than 100 of them later became Members of Parliament, including the new president, Kibaki, and many ministers of his cabinet. After the elections, a pre-pilot and then a pilot for a "Cash Transfer for Orphans and Vulnerable Children" (CT-OVC) were started, both financed by donors such as the Swedish International Development Cooperation Agency (SIDA), DFID, UNICEF, the United States Agency for International Development and World Bank. UNICEF also provided three technical advisors to the Kenyan government (Ouma and Adésínà 2019, 385). However, the influence of this kind of external actors is very difficult to assess. UNICEF continued lobbying, not least by financing study trips to Colombia and Jamaica where cash transfer programs existed. These trips made some key officials change their critical attitude toward cash transfer programs, including fears of dependency (Ikiara 2009, 21). Among the early key supporters was former Vice-President Awori. Conditionality was initially considered but then dropped. The Ministry of Finance considerably multiplied the initial budget allocation in subsequent years. This continued after the 2007 election, when opposition politicians were included in a Government of National Unity. The new Prime Minister Raila Odinga, who had narrowly lost the presidential elections to Kibaki, also became supportive after a study trip to India (Ikiara 2009, 21). Donors such as 
the World Bank, DFID, UNICEF and SIDA contributed. However, the World Bank contribution is a credit facility that has to be repaid. In this sense, the notion of donor support is misleading. Cautious domestic voices warned against rising debts (Ikiara 2009, 17). The second major cash transfer program is the "Hunger Safety Net Programme" (HSNP) in 2008, conceived and funded by DFID without much consultation with the Kenyan government (Ouma and Adésínà 2019, 386). Smaller programs include the "Older Persons Cash Transfer", the "Disability Grant" and the "Urban Food Subsidy" (Künzler 2016b).

After the election of the new president, Uhuru Kenyatta, in 2013 the "Urban Food Subsidy", advocated by NGOs Concern and Oxfam, was suspended in 2016. However, in February 2014 the "Disability Grant", the pensions-tested "Older Persons Cash Transfer" and the CT-OVC were expanded and consolidated under the name of "Inua Jamii Cash Programme". Remarkably, the HSNP, which was rather imposed on the Kenyan government, was not included. The "Inua Jamii Cash Programme" was again supported by a loan from the World Bank. In a speech on the occasion of its introduction, President Kenyatta presented this program as a responsibility of the government toward the population (RoK 2014). There were no references to questions of affordability or dependency of recipients. In recent years the program has been further expanded and an additional 500,000 Kenyans aged 70 years and above have been included by a top-down decision. The cash transfer program also includes NHIF cover for the elderly and aims at universal coverage of this age group. Finance Minister Rotich was cited by media in favor of this inclusion and without concerns regarding affordability or dependency (Nyataya 2017). Indeed, this quite remarkable expansion of social policies in Kenya did not trigger any significant public discussions about affordability and sustainability. This is not to say that there are no discussions about the growth of government expenditures. However, cash transfer programs are generally not blamed for this. President Kenyatta even legitimized the proposed levy of value added tax on petroleum products with references to free education and cash transfers to the elderly.

Donor support clearly worked in favor of the introduction of the orphans and vulnerable children (OVC) and HSNP cash transfers. While several donors were involved, they pushed in the same direction. 
However, there are important domestic co-drivers. It is hardly a coincidence that cash transfers were introduced in the context of growing political competition. Since 2003, the country has been governed by presidents and vice-presidents from different, highly personality-driven and thus constantly changing political parties. They have a short-term focus on their (re)election. In 2013, decentralization was introduced and political competition on the subnational level intensified. The expansion of cash transfers gave national-level politicians important leverage at the local level, as the local Member of Parliament is involved in the selection of beneficiaries. In the context of term limits and personality-driven political parties, politicians have incentives to incur debts, as neither they nor their parties will necessarily be in power when the debts have to be repaid. Domestic priorities are thus important intermediary factors that shape the way global goals and donor priorities are translated into national policies.

In contrast to this Kenyan experience, concerns of affordability and long-term sustainability are more important in Tanzania. By way of illustration, President Mkapa $(2005,61)$ called debts dangerous for the freedom of the country. This concern stems from the colonial past but is also reinforced by a political system where a dominant party has been in power since independence and has a self-conceived notion of its perpetual responsibility for the country. In line with this is a preference for more restricted social policies. ${ }^{11}$ In 2008, donors such as the World Bank, Japan, the USA and Norway supported a pilot project of the "Tanzania Mainland Social Action Fund" (TASAF) that paid a cash transfer on condition of regular school attendance by children or regular health checks for elderly ("Community-Based Conditional Cash Transfer", CB-CCT). This pilot followed a World Bank-funded workshop in 2005 (Ulriksen 2016a). Interestingly, the World Bank took officials on study trips to Ethiopia, Kenya and Jamaica, resulting in a different kind of policy learning than the Jamaica trip mentioned for the CT-OVC in Kenya. In Tanzania, key domestic players (politicians of the ruling party, Ministry

\footnotetext{
${ }^{11}$ One example is the program for most vulnerable children which, in contrast to Kenya, does not include a cash transfer but rather small in-kind transfers (Ulriksen 2016b, 5).
} 
of Finance, TASAF), the government and the World Bank alike favored conditional transfers and opted for scaling them up.

Concerning cash transfers, not much happened in the run-up to the 2010 elections, when the image of the ruling party was marred by highlevel corruption scandals. The focus of the ruling party was on fertilizer subsidies, whose coverage was expanded prior to the elections to include rice- and maize-growing districts (Kjær and Therkildsen 2013, 600). Members of the ruling party dominate the councils that choose the beneficiaries of the subsidies. This is an interesting case of policy learning: "Interviews with (...) party officials show that the role of subsidies in the Malawi elections inspired the (...) leadership" (Kjær and Therkildsen 2013, 601). The World Bank, previously against fertilizer subsidies, changed its stance and supported this expansion.

In 2012, the government approved the "Productive Social Safety Net" (PSSN) program that included a conditional cash transfer targeting the extremely poor population and a public work component (Ulriksen 2016a). The cash transfer component is rooted in the CB-CCT mentioned above and supported by the World Bank and other donors such as DFID and SIDA. In contrast to Kenya, in Tanzania the World Bank has a strong preference for a restricted cash transfer program that is in line with domestic political priorities. The PSSN has a strong productivist touch (Ulriksen 2016b, 17). According to Ulriksen (2016a), the idea of productivity and co-responsibility was an important argument for an upscaling of the conditional cash transfer (CCT) program. This does not mean that the government did not toy with the idea of a universal social pension, at certain moments favored by DFID and other donors as well as the Ministry of Labour. Announced ahead of the 2015 election, it has yet to be introduced. Instead, the government supported conditional cash transfers, which helped to convince donors to support the PSSN (Ulriksen 2016a). From a donor perspective, an additional advantage of the PSSN as opposed to the social pension was that the PSSN was already operational. For the government, the timing of the identification of additional beneficiaries of the scaled-up PSSN just ahead of the 2015 elections was politically advantageous. Nevertheless, there is lacking financial commitment with the CCT component of the PSSN (Jacob and Pedersen 2018, 21). Indeed, under the new president, Magufuli, the CCT compo- 
nent of the PSSN seems to have become less important than the public works element, in contrast to opposing donor preferences (Jacob and Pedersen 2018).

\section{The Interplay Between External Actors and National Factors}

\section{The Interplay Between External Actors and Domestic Factors in the Colonial Period}

This subsection attempts not only to compare the influence of colonialism with regard to similarities and differences between social policies in Kenya and Tanzania but also to discuss the role of domestic actors. Neither colonial Kenya's nor Tanganyika's social policies fit very well to Mkandawire's (2016) descriptions of labor reserve and cash crop economies. In Kenya there was a dual policy of segregation, imposed by particular colonial officials against the resistance of parts of the white settler population (Maxon 1980). However, there was no significant welfare system for white settlers. These settlers were in general often in conflict with colonial officers in Nairobi and the Colonial Office in London (Anderson and Throup 1985). However, they were less influential than their counterparts in classic examples of labor reserves such as South Africa. Against their interests, the colonial state intervened and encouraged African cash crop production alongside settler production. Thus, agricultural production could support the rural poor in colonial Kenya, as was the case in Tanganyika.

Consequently, the general orientation of colonial social policies was surprisingly similar, in contradiction to the theoretically expected differences. In both colonies there were isolated and short-lived colonial welfare initiatives in urban centers. This was in line with the vision of the Colonial Office in London that favored educated and urban working-class Africans (see Seekings, Chap. 5, this volume). However, it was in conflict with the 
rural focus of colonial officers in Kenya and Tanganyika. ${ }^{12}$ Local colonial officers impeded or even boycotted the initiatives of the disconnected Colonial Office (Lewis 2000; Eckert 2004). Concerned with the political legitimacy of colonial rule in rural areas, local colonial officers focused on efficient rural institutions that were able to provide social welfare.

The policy fields discussed were also less different than theory (Mkandawire 2016) assumes: Neither colony focused much on family allowances, and there were no comprehensive colonial pension schemes for formal sector workers outside the civil service. In these policy fields, local colonial officers and the Colonial Office in London shared quite similar positions. More in line with Mkandawire (2016), Kenya has a stronger focus on formal sector workers insofar as minimum wages were actually introduced. Also in support of Mkandawire's (2010, 2016) claim, colonial Kenya had a higher extractive capacity and a higher per capita tax income. A more indirect effect linked to the lower extractive capacity of Tanganyika is that the late colonial state spent less and placed more emphasis on local-level engagement than Kenya. Exemplary in this respect was famine relief: While famine relief involved the central colonial government in Kenya, it was not a government obligation but rather an ethical imperative at the district level in Tanganyika. This also shows that it is too simplistic to equate colonial influences with external influences, as in this policy field colonial officers based in Kenya and Tanganyika clearly mattered. Local actors are also important for other forms of external influence, as the next subsection will show.

\section{International Donors and Their Interplay with National Factors}

Concerning the influence of international donors, both countries support the theoretical assumption that the influence of international donors was quite high during the period of structural adjustment. Both countries were in serious financial troubles, and there were no alternatives

\footnotetext{
${ }^{12}$ In Kenya, their opposition to urban welfare initiatives was strongly supported by white settlers (Lewis 2000, 244).
} 
available to avoid the introduction of user fees. However, there were differences in terms of room for manoeuver. Tanzania was quite quickly sanctioned with a reduction in aid and pushed to introduce structural adjustment measures. Kenya had more leverage in the international system, being an important ally of Western powers in a region with socialist governments and civil wars (see Mioni and Petersen, Chap. 3, this volume). While the introduction of user fees has been on the domestic agenda for several years, it took World Bank pressure to introduce them swiftly. However, Kenya could sway policies with regard to domestic concerns without being sanctioned. Finally, another crucial effect of donor influence in both countries is the introduction of multiparty elections.

The empirical observations in the fields of health care and education after the turn of the millennium point to a number of conclusions. First, where donor policies were clear and significant support available (free primary education), countries were quick to follow the international prescription. These prescriptions were important in electoral campaigns, as they have a universal electoral appeal. Where there was no significant donor support, countries nevertheless introduced policies in line with the international prescriptions (free secondary education), but with quite a significant time lag. No clear picture emerges where donor prescriptions are not clear and support is indirect or fragmented (health care). In both cases, domestic politics are important for the timing of social policy changes: They cluster around elections. Different social policy fields might be substitutes. There were never two major social policy changes around one election. However, there were also elections without major social policy reform. This concerned the second terms of Kibaki (2007) and Kikwete (2010), but not the second term of Kenyatta (2017). A final observation is that there is commitment to cost-sharing in the health sector in Tanzania, while Kenya introduced a policy of fee exemption policies.

The influence of international donors seems to be more limited in another social policy field that has also become more important since the turn of the millennium. Concerns with affordability shaped the way in which Tanzania made use of a World Bank credit for the introduction of a partly conditional cash transfer program. In Kenya, such concerns are quite absent, and unconditional cash transfers have been expanded in 
recent years. This difference is also reinforced by the differences in the countries' respective contemporary political systems. While there is electoral pressure in Tanzania and the implementation of the PSSN was sped up before the 2015 elections, the ruling party has been in power since independence, and long-term financial sustainability is embedded in its self-conception. In contrast, since 2003 Kenya has been governed by presidents and vice-presidents from different, highly personality-driven and thus constantly changing political parties with short-term policies focused on the next elections. Kenya spends more on social assistance. ${ }^{13}$ Consequently, the debt level is much higher in Kenya, where social policies are continuously expanded without much concern for affordability. ${ }^{14}$ In addition to differences in the contemporary political systems and resulting different kinds of electoral pressure, this key difference between Kenya and Tanzania is rooted in the colonial past. In line with the expectations of Mkandawire (2016), former colonial labor reserve Kenya has indeed got broader tax-financed social policies and is less concerned with affordability.

\section{Conclusion}

This conclusion starts by discussing the influence of external actors in Kenya and Tanzania. In the colonial period, the Colonial Office in London tried to shape the general outline of social policies and developed a focus on educated and urban working-class Africans. Colonial officers in Kenya and Tanganyika subverted this vision with their rural focus. Consequently, colonial welfare initiatives in urban centers in Kenya and

\footnotetext{
${ }^{13}$ World Bank (2018b) data show that the total spending on social assistance as a percentage of GDP is clearly higher in Kenya (2.52\% in 2010) compared to Tanzania (0.29\% in 2009). More recent data will be higher in both countries, but the effects of the new cash transfer programs still have to be researched. Interestingly, again according to older data, Kenya's social assistance spending is more pro-poor than Tanzania's: $8 \%$ of the benefits went to the poorest quintile in Kenya, compared to $1 \%$ in Tanzania (World Bank 2018b). In both countries, a considerable part of government expenditure goes to civil service pensions.

${ }^{14}$ Debt was at US $\$ 41.91$ billion in June 2017, compared to US $\$ 23.69$ billion in Tanzania (East African 2017). Looking at time series data from the World Development Indicators (World Bank 2018a), debt services have been higher in Kenya than in Tanzania throughout the period from 1971 to 2016. Of course, this level of debt is not only caused by social policies.
} 
Tanganyika were surprisingly similar but isolated and short-lived. While white settlers and African actors also tried to shape social policies, local colonial officers were key. Concerning the absence of family allowances and of a comprehensive pension scheme for formal sector workers outside the civil service, there was no conflict of interests between local colonial officers and the Colonial Office. In these policy fields, Kenya and Tanganyika fit very well into the general pattern of British colonies. Finally in another policy field, famine relief, local colonial actors acted without reference to the Colonial Office.

Concerning the influence of external actors in the post-colonial period, there is no systematic theory explaining how successful international donors are with influencing domestic social policies. The empirical evidence for the room for manoeuver available to national governments is ambiguous. Donor influence varies between policy fields and is bigger if donor leverage is big and if donors support the same policies (e.g. during structural adjustment programs). Poorer countries have less leverage to resist policy recommendations of key international donors. The influence of international donors is limited if their policy proposals adversely affect the priorities of key domestic policy actors and especially if a country has leverage in the international system. Domestic political elites might have other priorities than international donors and might be reluctant to scale up pilot projects or assume financial responsibilities after donor funding has come to an end. Empirical evidence of domestic elite priorities includes a focus on economic growth and productivity and worries about dependency. In addition, domestic political elites might choose social policies because of their electoral appeal, without the support of international donors. This underlines the importance of domestic factors for social policies.

In both the colonial and the post-colonial periods, certain local actors matter as mediators of external influences. In the colonial period, key colonial officers subverted the visions of the Colonial Office if they deemed them inappropriate. They also had scope for their own initiatives. In both cases, concerns with the legitimacy of colonial rule in rural areas were important motivations. White settlers and African actors are less able to shape colonial social policies. In the post-colonial period, domestic political elites (especially presidents and influential ministers) 
are key. They resist and sometimes subvert donor initiatives if their priorities are affected and donor leverage is limited. With or without donor support, domestic political elites have a certain preference for social policies that fit their priorities (focus on economic growth and productivity) and have an electoral appeal. These policies are not necessarily supported by the bureaucrats that have to implement them. Bureaucrats as well as other domestic actors, such as NGOs, seem to matter more for the technical aspects of social policies than landmark decisions.

An important result that indicates some research gaps is the more indirect but lasting effect linked to the lower extractive capacity of Tanganyika. In line with the expectations of Mkandawire (2016), former colonial labor reserve Kenya does indeed have broader tax-financed social policies. It is less concerned with affordability. Zanzibar, another colonial labor reserve, shows a similar pattern. In 2016 it introduced a universal, taxfinanced old-age pension (Seekings 2016). As in Kenya, the discourse centers more on government responsibility than on fears of dependence. Further research could focus on other countries of similar type that are less researched and might offer contrasting evidence, for example Burundi, Madagascar or Eswatini. Also worth analyzing are the countries belonging to what Amin $(1972,504)$ called the "Africa of the concessionowning companies". Also Mkandawire $(2016,2)$ uses this term, without saying much about these countries concentrated in Central Africa. Indeed, as this group consists of Francophone and some Iberophone countries, they constitute an astonishing gap in the social policy literature.

\section{References}

Alviar, Carlos, and Roger Pearson. 2009. Cash Transfer for Vulnerable Children in Kenya: From Political Choice to Scale-Up. Social and Economic Policy Working Paper. New York: UNICEF.

Amin, Samir. 1972. Underdevelopment and Dependence in Black AfricaOrigins and Contemporary Forms. Journal of Modern African Studies 10 (4): 503-524. 
Anderson, David, and David Throup. 1985. Africans and Agricultural Production in Colonial Kenya: The Myth of the War as a Watershed. Journal of African History 26 (4): 327-345.

Barkan, Joel D. 1984. Comparing Politics and Public Policy in Kenya and Tanzania. In Politics and Public Policy in Kenya and Tanzania, ed. Joel D. Barkan, Revised ed., 3-42. New York: Praeger Publishers.

Berman, Bruce, and John Lonsdale. 1992. Crises of Accumulation, Coercion \& The Colonial State: The Development of the Labour Control System, 1919-29. In Unhappy Valley. Conflict in Kenya \& Africa. Book One: State \& Class, ed. Bruce Berman and John Lonsdale, 101-126. Oxford: James Currey. Bossert, Albrecht. 1985. Traditionelle und modern Formen sozialer Sicherung in Tanzania: Eine Untersuchung ihrer Entwicklungsbedingungen. Berlin: Duncker \& Humblot.

Boyle, Elizabeth Heger, Fortunata Songora, and Gail Foss. 2001. International Discourse and Local Politics: Anti-Female-Genital-Cutting Laws in Egypt, Tanzania, and the United States. Social Problems 48 (4): 524-544.

Bryceson, Deborah Fahy. 1990. Food Insecurity and the Social Division of Labour in Tanzania, 1919-85. New York: St. Martin's Press.

Clayton, Anthony, and Donald C. Savage. 1974. Government and Labour in Kenya, 1895-1963. London: Frank Cass.

Cliffe, Lionel. 1973. Underdevelopment or Socialism? A Comparative Analysis of Kenya and Tanzania. Discussion Paper. Brighton: IDS.

D’Arcy, Michelle. 2013. Non-State Actors and Universal Services in Tanzania and Lesotho: State-Building by Alliance. Journal of Modern African Studies 51 (2): 219-247.

East African. 2017. Looming Risks as Kenya, Tanzania Debt Levels on the Rise. October 24. Accessed 15 May 2018. http://www.theeastafrican.co.ke/business/Looming-risks-as-Tanzania\%2D\%2DKenya-debt-levels-on-therise/2560-4153072-hwx7egz/index.html.

Eckert, Andreas. 2004. Regulating the Social: Social Security, Social Welfare and the State in Late Colonial Africa. Journal of African History 45 (3): 467-489. Frankema, Ewout, and Marlous van Waijenburg. 2014. Metropolitan Blueprints of Colonial Taxation? Lessons from Fiscal Capacity Building in British and French Africa, c. 1880-1940. Journal of African History 55: 371-400.

Ikiara, Gerrishon K. 2009. Political Economy of Cash Transfers in Kenya. A Report Prepared for the Overseas Development Institute. London: ODI. Jacob, Thabit, and Rasmus Hundsbæk Pedersen. 2018. Social Protection in an Electorally Competitive Environment (1): The Politics of Productive Social Safety 
Nets (PSSN) in Tanzania. ESID Working Paper No. 110. Manchester: University of Manchester.

Kaasch, Alexandra. 2013. Contesting Contestation: Global Social Policy Prescriptions on Pensions and Health Systems. Global Social Policy 13 (1): 45-65.

Kjær, Anne Mette, and Ole Therkildsen. 2013. Elections and Landmark Policies in Tanzania and Uganda. Democratization 20 (4): 592-614.

Kpessa, Michael, and Daniel Béland. 2012. Transnational Actors and the Politics of Pension Reform in Sub-Saharan Africa. Review of International Political Economy 19 (2): 267-291.

Künzler, Daniel. 2007. L'éducation pour quelques-uns? Enseignement et mobilité sociale en Afrique au temps de la privatisation: le cas du Bénin. Paris: L'Harmattan.

2016a. The Politics of Health Care Reforms in Kenya and Their Failure. socialpolicy.ch 2016/1, article 1.4 .

— 2016b. Social Security Reforms in Kenya: Towards a Workerist or a Citizenship-Based System? International Social Security Review 69 (1): 67-86. . 2016c. Health Care and Old Age Pensions in Latin America and Africa: Introduction to the Issue. socialpolicy.ch 2016/1, article 1.1.

Künzler, Daniel, and Michael Nollert. 2017. Varieties and Drivers of Social Welfare in Sub-Saharan Africa: A Critical Assessment of Current Research. socialpolicy.ch 2017/2, article 2.1 .

Languille, Sonia. 2015. Ward Secondary Schools, Elite Narratives and Nyerere's Legacy. In Remembering Nyerere in Tanzania. History, Memory, Legacy, ed. Marie-Aude Fouéré, 305-337. Dar es Salaam: Mkuki na Nyota.

Lewis, Joanna. 2000. Empire State Building. War \& Welfare in Kenya, 1925-52. Oxford: James Currey, Nairobi: EAEP and Athens: Ohio University Press.

Maxon, Robert M. 1980. John Ainsworth and the Making of Kenya. Washington: University Press of America.

Mkandawire, Thandika. 2010. On Tax Efforts and Colonial Heritage in Africa. Journal of Development Studies 46 (10): 1647-1669.

. 2016. Colonial Legacies and Social Welfare Regimes in Africa: An Empirical Exercise. Working Paper 2016-4. Geneva: UNRISD.

Mkapa, Benjamin W. 2005. Uwazi na Ukweli. Rais wa watu azungumza na Wananchi. Kitabu cha nne. Dar es Salaam: Mkuki na Nyota Publisher.

Mwabu, Germano. 1995. Health Care Reform in Kenya: A Review of the Process. Health Policy 32: 245-255.

Neubert, Dieter. 1986. Sozialpolitik in Kenya. Münster: LIT. 
Niño-Zarazúa, Miguel, Armando Barrientos, Samuel Hickey, and David Hulme. 2012. Social Protection in Sub-Saharan Africa: Getting the Politics Right. World Development 40 (1): 163-176.

Nyataya, Jared. 2017. Sh24bn Needed for Medicare, Elderly. Daily Nation. https://www.nation.co.ke/news/Plan-to-protect-elderly-to-cost-countrySh24bn/1056-3872780-41 pnir/index.html.

Ouma, Marion, and Jimi Adésínà. 2019. Solutions, Exclusion and Influence: Exploring Power Relations in the Adoption of Social Protection Policies in Kenya. Critical Social Policy 39 (3): 376-395.

Pedersen, Rasmus Hundsbæk, and Thabit Jacob. 2018. Social Protection in an Electorally Competitive Environment (2): The Politics of Health Insurance in Tanzania. ESID Working Paper 110. Manchester: University of Manchester. Republic of Kenya (RoK). 2014. President's Speech During the Official Launch of Inua Jamii Cash Programme at Ihura Stadium in Murang'a County on Tuesday February 4, 2014. No longer available on http://www.president.go.ke.

Schmitt, Carina. 2015. Social Security Development and the Colonial Legacy. World Development 70: 332-342.

Seekings, Jeremy. 2005. Prospects for Basic Income in Developing Countries: A Comparative Analysis of Welfare Regimes in the South. CSSR Working Paper 104. Rondebosch: Centre for Social Science Research.

- 2016. The Introduction of Old Age Pensions in Zanzibar. CSSR Working Paper 393. Cape Town: Centre for Social Science Research.

Simpson, Joshua P. 2018. Do Donors Matter Most? An Analysis of Conditional Cash Transfer Adoption in Sub-Saharan Africa. Global Social Policy 18 (2): 143-168.

Singh, Makhan. 1969. History of Kenya's Trade Union Movement to 1952. Nairobi: East African Publishing House.

Ulriksen, Marianne S. 2016a. Ideational and Institutional Drivers of Social Protection in Tanzania. UNU-WIDER Working Paper 2016/142. Helsinki: UNU-WIDER.

- 2016b. The Development of Social Protection Policies in Tanzania, 2000-2015. CSSR Working Paper No. 377. Cape Town: University of Cape Town.

UNDP. 2018. Human Development Indicators. Dataset. Accessed 4 May 2018. http://hdr.undp.org/en. 
World Bank. 2018a. World Development Indicators. Dataset. Accessed 4 May 2018. https://datacatalog.worldbank.org/dataset/world-development-indicators.

- 2018b. The Atlas of Social Protection: Indicators of Resilience and Equity. Dataset. Accessed 4 May 2018. https://datacatalog.worldbank.org/dataset/ atlas-social-protection-indicators-resilience-and-equity.

Open Access This chapter is licensed under the terms of the Creative Commons Attribution 4.0 International License (http://creativecommons.org/licenses/ by/4.0/), which permits use, sharing, adaptation, distribution and reproduction in any medium or format, as long as you give appropriate credit to the original author(s) and the source, provide a link to the Creative Commons licence and indicate if changes were made.

The images or other third party material in this chapter are included in the chapter's Creative Commons licence, unless indicated otherwise in a credit line to the material. If material is not included in the chapter's Creative Commons licence and your intended use is not permitted by statutory regulation or exceeds the permitted use, you will need to obtain permission directly from the copyright holder.

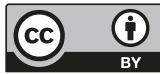

